Non-Being: New Essay on the Metaphysics of Non-Existence, Sara Bernstein and Tyron Goldschmidt (eds.), Oxford: Oxford University Press, 82-96, 2021.

\title{
How Can Buddhists Prove That Non-Existent Things Do Not Exist?
}

\author{
Koji Tanaka
}

School of Philosophy

Research School of Social Sciences

Australian National University

Koji.Tanaka@anu.edu.au

\section{Buddhist Philosophers and Non-Existence}

Buddhist philosophers are critical of the generous ontology advocated by nonBuddhist Indian philosophers. ${ }^{1}$ They reject the existence of all sorts of things which are important for the non-Buddhist. For instance, the Buddhist holds that the self does not exist. That there is no self is an important Buddhist doctrine. Whatever this doctrine is supposed to mean, the Buddhist has to argue against those who are convinced that the self does exist and there are plenty of those who implicitly or explicitly believe in the self. The problem with Buddhist philosophers in arguing against their opponent is that they agree with non-Buddhists that one cannot prove a thesis whose subject is non-existent. This agreement has put Buddhist philosophers in a difficult situation. How can they argue against their opponents and show that the self and all other things that Buddhists take to be non-existent do not exist while agreeing that one cannot prove a thesis whose subject is non-existent?

\footnotetext{
${ }^{1}$ This seems to change as Buddhism went East to China (and Korea and Japan). See Tanaka (forthcoming). In this paper, I am mostly concerned with Buddhist philosophers who flourished in India and Tibet.
} 
The problem for Buddhist philosophers is not confined to their central doctrines. They are actually much worse as they tend to be global error theorists. An error theorist typically holds that there are no facts of the matter in a specific context. An error theorist about morality holds that there are no moral facts. Some error theorists further hold that there are no truths about morality. For error theorists about morality, any moral discourse is, strictly speaking, not true (Joyce (2016)). Similarly, an error theorist about fictions hold that there are no truths about fictional characters. For them, it is not true that Sherlock Holmes lived in 221B Baker Street, London. Some error theorists also hold that there are no facts or truths about fictional characters even within fictions as the properties attributed to them are not factual matters. According to those error theorists about fictional characters, it is, strictly speaking, not true that Harry Potter was pretending to be dead when Voldemort cast the killing curse (Avada Kedavra) with the Elder Wand even within the Harry Potter books. For them, any claim about fictional characters is not truth-apt (Brock (2002)).

If we generalise an error theory to any context, we get global error theory. A global error theorist holds that there are no facts or truths about anything. Many Buddhist philosophers, at least those in India and Tibet, can be characterised as global error theorists who held that there are no facts or truths about anything as there is not anything that really exists. This does not make them nihilists as they do think that things do have quasi-existence (conventional existence (samvrtisat)). ${ }^{2}$ But non-Buddhist philosophers are typically not global error theorists and hold that a lot of things do really exist. Buddhist philosophers, thus, have to argue against them about many things which they do not think really exist and about which there are not really any truths.

Demonstrating that Buddhist philosophers can be described as global error theorists is beyond the scope of this paper. ${ }^{3}$ For the sake of this paper, I will assume that Buddhist philosophers are largely global error theorists. The question then is: how can they claim that it is true that something which does not exist does not exist when the opponent holds that it exists?

In this paper, I will first present a difficulty that Buddhist philosophers have faced in proving that what they take to be non-existent does not exist. I will then survey two main solutions that they have provided. Those 'solutions' may not solve the problem or solve the problem but creates other problems. I will not survey the Buddhist treatment of the problem of proving about non-existence in

\footnotetext{
${ }^{2}$ What exactly this means is a complicated issue. See, for instance, Cowherds (2011) for a discussion.

${ }^{3}$ This is a difficult and controversial task and I do not pretend that describing Buddhist philosophers as largely global error theorists is widely accepted. However, see Tillemans (2016) who describes some Buddhist philosophers as global error theorists even though he does not use the phrase 'global error theory' or 'global error theorist'.
} 
order to present a new solution that we have yet to see. Instead, I will articulate a problem about non-existence that is unique to Buddhist philosophers. I will do so in order to present an interesting puzzle about non-existence that has largely escaped attention in the 'Western' literature.

\section{2 Āśrayāsiddha}

Buddhist discussion of non-existence centres around āsrayāsiddha (unestablished basis). It is (or was) commonly accepted in India that when the 'basis' (āśraya) or subject (dharmin) of a thesis (paksa) is unestablished, that is to say, non-existent, the thesis cannot be established or proved. The fallacious nature of $\bar{a}$ śrayāsiddha is commonly accepted by both Buddhist philosophers and their philosophical opponents (i.e., non-Buddhist Indian philosophers). In everyday situation, we may not be puzzled when someone claims that the pretension of Harry Potter when he was struck by Voldemort cannot be proved to be real because of his non-existence. But, about things that matter philosophically such as the reality or unreality of the self, the threat of the fallacy of āsrayāsiddha is a real issue.

For Buddhist philosophers, āśrayāsiddha becomes particularly problematic as they are typically global error theorists. The problem is historically acute in two contexts which are concerned with existence generally: Buddhist 'proofs' of momentariness and Buddhist, particularly (later) Madhyamaka, proofs of the absence of intrinsic nature (nihsvabhāvatā). ${ }^{4}$ In both contexts, Buddhist philosophers want to prove a thesis whose basis or subject is non-existent. In the context of momentariness, Buddhists want to prove that whatever exists is momentary (i.e., if something exists, it exists only momentarily). If we contrapose it within the universal quantifier (most, if not all, Buddhist philosophers accept contraposition as valid), what they want to prove is that whatever is non-momentary is non-existent. But, for the Buddhists, there cannot be anything which is non-momentary. So the thesis of momentariness has a subject (or subjects) that is (or are) non-existent. Hence Buddhist philosophers have to come up with a way around āśrayāsiddha (Matilal (1970)). In the context of the absence of intrinsic nature (nihsvabhāvatā), if something lacks intrinsic nature, it does not exist for the opponent. Buddhists, in particular Mādhyamikas, would have to agree to this to a certain degree since, for them, there are not really any facts about anything and so they cannot claim, for instance, that the self does not really exist. So the thesis that everything lacks

\footnotetext{
${ }^{4}$ Madhyamaka school consists of Buddhist philosophers who are the followers of Nāgārjuna (2nd CE) known for his doctrine of emptiness. Following modern convention, I will use 'Madhyamaka' to refer to the school or thought and 'Mādhyamika' to refer to people who belong to the school or hold the thought.
} 
intrinsic nature has a subject (or subjects) that does not (or do not) exist. ${ }^{5}$

Given the importance of momentariness and the absence of intrinsic nature (or emptiness (śünyatā)), Buddhist philosophers have to take the fallacy of āśrayāsiddha seriously. Historically, Buddhist philosophers have suggested mainly two solutions to āśrayāsiddha. In the rest of the paper, I will explain what I take those solutions to be and how they developed in the Buddhist philosophical tradition.

\section{Avoiding the Fallacy of Āśrayāsiddha Part I}

Buddhist discussions on $\bar{a}$ śrayāsiddha tend to start with the definition of (valid) thesis (paksalakșana) that Dignāga (480-540 CE) provided in his Pramānasamuccaya:

[A valid] thesis is one which is intended by [the proponent] himself as something to be stated in its proper form alone; [and] with regard to [the opponent's] own subject, it is not opposed by perceptible objects, by inference, by authority or by what is commonly recognised. (Pramānasamuccaya III, k. 2) ${ }^{6}$

Dignāga was the main figure, alongside Dharmakîrti (7th CE), who laid down the foundation for the Buddhist study of epistemology and logic, in particular, the study of the methods for proof and acquisition of knowledge (pramāna). The particular concern for Dignāga was to undermine and disprove the scriptural authority of the Vedas, the authoritative texts which are said to prove a number of things for non-Buddhist philosophers in India. Dignāga argued against the authoritative words ( $\bar{a}$ ptavāda) as proving anything on their own and argued for only two means of acquiring knowledge: perception (pratyaksa) and inference (anumāna). Dignāga, Dharmakīrti and those Buddhist philosophers who have followed their lead have generally assumed that what we can know depends on how we can know it. That is, to use modern epistemological terminology, they are generally reliabilists. $^{7}$ They do not think that the cognitive state you happen to arrive at counts as knowledge. Cognition has to go through particular transformation for the resulting cognitive state to count as a knowledge state. ${ }^{8}$

Buddhist philosophers who came after Dignāga have generally taken his definition to mean that the property to be proved 'with regard to [the proponent's] own subject', i.e., the thesis that the proponent is arguing for, should not be opposed by any (valid) means of acquiring knowledge. More importantly for our purpose,

\footnotetext{
${ }^{5}$ See Kamalaśîla's (740-795 CE) Madhyamakāloka. A translation can be found in Keira (2004).

${ }^{6}$ This translation is from Tillemans (1999): 172.

7 'Reliabilists' and 'reliabilism' are terms that I am attributing to the Buddhists rather than the translations of any of the terms they use.

${ }^{8}$ See, for instance, Patil (2009), Tillemans (1999) and Tanaka (2013).
} 
they have also taken the definition to mean that the proponent's subject as well as the property to be proved (sädhyadharma) must be existent (Tillemans (1999): 172). Dignāga himself did not seem to have implied that the proponent's subject must be existent by his definition. However, he did seem to have thought that $\bar{a} s$ rayāsiddha is a fallacy and it is to be avoided as he was aware of the difficulty involved in proving that what he took to be non-existent does not indeed exist.

The issue of āsrayāsiddha comes out distinctly for Dignāga in the context of discussing Primordial Matter (pradhāna) whose existence the non-Buddhist Sāmkhya philosophers accept but Buddhist philosophers reject. He is concerned with discussing two different arguments in connection with Primordial Matter of the Sāmkhya school. First, he discusses the Sāmkhya arguments that allegedly show the existence of Primordial Matter. In those arguments, Sāmkhya philosophers argue for the existence of Primordial Matter from the general characteristics that all individual things share in common. Second, he discusses the Buddhist arguments showing the non-existence of Primordial Matter. For the Buddhist, even talking about these two kinds of arguments invites the charge of ásrayāsiddha as the subject matter of both kinds of arguments is non-existent. Dignāga seems aware of this and tries to avoid the charge. He offers different solutions in relation to the two kinds of arguments. Let's look at how he tries to avoid the fallacy of ásrayāsiddha in relation to the two kinds of arguments involving Sāmkhya's Primordial Matter.

In response to the Sāmkhya arguments that purportedly show the existence of Primordial Matter, Dignāga says:

[Sāmkhya philosophers] should formulate the thesis as 'The various individuals certainly possess one and the same cause [i.e., pradhāna], in which case they do not prove [directly the existence of] the Primordial Matter. ${ }^{9}$

He is suggesting here that the Sāmkhya thesis that Primordial Matter exists can be paraphrased in a way that the Buddhist can accept (Tillemans (1999): 174-175). Buddhist philosophers can accept the existence of cause and so they do not have any trouble talking about 'one and the same cause' of various individuals. They do, of course, reject the existence of such a cause; nevertheless, they can understand what the Sạmkhya thesis states when it is paraphrased in this way. Once they establish the possibility of engaging with the Sāmkhya thesis, the Buddhist can go on to reject it. In relation to the Sāmkhya arguments for the existence of Primordial Matter, thus, Dignāga offers the strategy of paraphrase in order to avoid the charge of āśrayāsiddha. This is also the strategy that Dharmakīti employs in his discussion of the proponent's own intended subject (svadharmin) in his Pramānavārttika IV.

\footnotetext{
${ }^{9}$ Nyāyamukha, the translation is from Tillemans (1999): 175.
} 
In relation to the Buddhist argument for the non-existence of Primordial Matter, Dignāga offers a different solution, however:

When they [i.e., the Buddhists] argue that [Primordial Matter] does not exist [because of nonperception], 'nonperception' is a property of the imagined object. ${ }^{10}$

The Buddhist metaphysical framework that is assumed here is that only particulars exist. ${ }^{11}$ Even though inference is a valid means of acquiring knowledge, it can give us only conceptual knowledge as it operates on the general characterisations of objects. Having conceptual knowledge is, however, not a proof of existence as only particulars exist according to the metaphysical view that Dignāga assumes and conceptual knowledge relies on universals. The proof of the existence of objects ultimately rests on perception which is the means by which one can acquire knowledge about particulars. So if Primordial Matter can be said to exist, we have to be able to perceive it. However, we cannot perceive Primordial Matter, so Dignāga claims. Hence, so the argument goes, Primordial Matter does not exist. This argument is valid assuming that modus tollens is valid. But, in order for it to be effective, Dignāga has to be able to talk about Primordial Matter. He does this by identifying it as an imagined object meaning that Primordial Matter is a conceptual object. As inference operates on the conceptual objects that are characterised by general features, Primordial Matter can then be talked about meaningfully and, thus, it can be the subject of a proof showing that it does not exist.

While Dignāga does offer the introduction of conceptual objects as a solution to the charge of áśrayāsiddha in relation to the positive proof that Primordial Matter is non-existent, he seems to abandon it as a way to avoid the charge. Dignāga might have raised it as a possible solution, but he did not seem to have thought that invoking conceptual objects is a good way to prove anything and he avoided proving anything via conceptual objects in his later writings (Katsura (1992)).

Dharmakīti (7th CE), the main philosopher who developed on the work of Dignāga on epistemology and logic, also tended to use the strategy of paraphrase rather than conceptual object in his discussion on the topic about non-existent things. In his Pramānavārttika IV, k. 144-45, Dharmakīti considers the antiSāmkhya argument that 'pleasure, pain and bewilderment' are not the permanent nature of the 'transformations' (vikrti) taking place in the world. Sāmkhya school

\footnotetext{
${ }^{10}$ Nyāyamukha, the translation is from Tillemans (1999): 175.

${ }^{11}$ I should note that not all Buddhist philosophers accept this metaphysical view. Mādhyamikas, for instance, reject the existence of not only universals but also particulars when the existence is understood as real, as opposed to quasi, existence. The metaphysical view that Dignāga is operating with, however, accepts the existence of particulars.
} 
takes them to be the (essential) qualities (gunas) of Primordial Matter. But, because Dharmakirti rejects the existence of Primordial Matter, he cannot be talking about pleasure, pain and bewilderment that are the qualities of what he takes to be non-existent, so the Sāmkhya retorts. In response, Dharmakīrti paraphrases them and claims that the subject matter of his anti-Sāmkhya argument are not the qualities of Primordial Matter but the pleasure, pain and bewilderment that ordinary folks feel. Because everyone, Buddhist or otherwise, accepts these ordinary feelings are real entities (vastubhüta) (they are in our experiences), Dharmakīrti goes on to refute the Sāmkhya thesis that pleasure, pain and bewilderment are permanent (Tillemans (1999): 178-179). In Pramānavārttika IV, k. 141-142, Dharmakīrti offers a parallel discussion about space (Tillemans (1999): 179-180).

The solution to the fallacy of āśrayāsiddha for early Buddhist epistemologists/logicians such as Dignāga and Dharmakīrti was, thus, the method of paraphrase. Buddhist philosophers who came after Dignāga and Dharmakīrti, however, largely took the introduction of conceptual objects as the main route to avoid $\bar{a}$ śrayāsiddha. Before considering how the method of conceptual objects became the main solution to the fallacy of āsrayāsiddha, I will say a few words about the two approaches. That will help us see the distinction between them as well as what is at stake for Buddhist philosophers in choosing which solution to adopt.

\section{Paraphrase vs. Conceptual Objects}

The method of paraphrase Dignāga and Dharmakīrti appeal to in responding to the Sāmkhya charge of áśrayāsiddha might not be thought to be effective. Dharmakīrti claims that he can legitimately entertain the thesis that pleasure, pain and bewilderment are permanent in order to refute it by paraphrasing 'pleasure, pain and bewilderment' and rendering it as 'pleasure, pain and bewilderment of ordinary folks'. Of course, if that's the strategy, the Sāmkhya philosopher can respond by saying that Dharmakirti simply changed the subject and has not refuted the Sāmkhya thesis. The thesis that Dharmakirti rejects is that the pleasure, pain and bewilderment that ordinary folks experience are permanent. But the thesis that the Sāmkhya is putting forward is that the pleasure, pain and bewilderment which are the qualities of Primordial Matter are permanent. Paraphrasing alone does not allow Dharmakīrti to refute the Sāmkhya thesis.

The situation is analogous to the following Cookie Monster scenario. Suppose that your child says that there is Cookie Monster in the closet. You might try to convince her that that is not the case by saying that Cookie Monster is in the room by holding a soft toy version of Cookie Monster. She then says: 'No, daddy, that's a toy Cookie Monster and the real Cookie Monster is in the closet!' Sure enough, the fact that a toy Cookie Monster is not in the closet does not prove that the real 
Cookie Monster is not in the closet. 'Silly daddy!'

An analogy like this might be thought to show that the method of paraphrase is not really a solution to the fallacy of ásrayāsiddha. But what would you say in response to the child who essentially accuses you of changing the subject? I think the answer should be: nothing. You know that there is no such thing as the real Cookie Monster. It is a character enacted by a puppet on a TV show. Even if you got hold of the puppet actually used on the show and held it in your hand saying: 'Look! Cookie Monster is here and not in the closet!', you would, most likely, still get the same response. So there is not much point in arguing at that point.

This may just be a silly story about Cookie Monster. I am sure that every parent simply shrugs off by this point. But, for a global error theorist like a typical Buddhist philosopher, a situation like this is ubiquitous. For a global error theorist, nothing can be said to really exist. They can talk about 'replicas' like a toy Cookie Monster. But there is nothing other than those 'replicas' that they can claim to exist. So when someone claims that something really exists, all a global error theorist can do is to put their hands up and surrender. To be a consistent global error theorist is to be a quietist. ${ }^{12}$

The device that Buddhist philosophers use to theorise about this aspect of global error theory is the two truths (or two realities) theory: ultimate truth/reality (paramārthasatya) and conventional truth/reality (samvrtisatya)). ${ }^{13}$ What exactly they are is a matter of debate both for traditional Buddhist philosophers and contemporary scholars of Buddhist philosophy. ${ }^{14}$ Depending on which Buddhist philosopher or Buddhist scholar we have in mind, what counts as ultimately true and what can be said to ultimately exist differ. One thing is clear, however. For Buddhist philosophers, the number of things that can be said to ultimately exist and have ultimate truth about is very limited if any. Some Madhyamaka philosophers such as Candrakīrti (570-650 CE) seem to think that the realm of ultimately existing entities is empty. In contrast, this realm is rather vast and a very important one for non-Buddhist philosophers. Primordial Matter of the Sāmkhya, for instance, is part of the realm of ultimately existing entities. Buddhist philosophers disagree amongst themselves how small this realm should be but they all agree that it is a lot smaller than what non-Buddhist philosophers hold it to be. In nuce, Buddhist philosophers advocate a very sparse ontology and truth in the context of ultimate truth/reality. If someone insists that something ultimately exists and there are ultimate truths about them, all Buddhist philosophers can do is ... (being silent), since, for them, there is nothing that can be said about it.

The above discussion may show that the Buddhist philosophers who advocate

\footnotetext{
${ }^{12}$ See a quietist treatment of Madhyamaka in Tillemans (2016).

13 'Satya' can be rendered as 'truth' or 'reality' depending on the context.

${ }^{14}$ For an introduction to the two truths, see, for instance, the Cowherds (2011).
} 
the method of paragraph as a solution to âśrayāsiddha can be quietists and be consistent with their other commitments. However, it is not clear that it fares well as a way to avoid the fallacy of $\bar{a} s$ rayāsiddha. This is because there is no guarantee that the opponent's thesis can always be paraphrased. If someone makes up an entity and claims that it really exists, there may not be anything in their conventional reality that they can appeal to in order to paraphrase it. Paraphrasing is, thus, not a guaranteed method of avoiding the fallacy of āśrayāsiddha. ${ }^{15}$

The method of introducing conceptual objects, on the other hand, can guarantee that there is an entity that the Buddhist can talk about and, thus, that the fallacy of āśrayāsiddha can be avoided. For whatever the subject matter the proponent's thesis is about, one can posit a conceptual object that corresponds to it.

So, if the issue is only about $\bar{a} s$ rayāsiddha, the method of positing conceptual objects may be a better way to deal with the issue. However, it essentially reintroduces the entities that the Buddhist wants to avoid. Subscribing this method is, thus, like Occam (or Ockham) multiplying the number of entities in order to demonstrate the law of parsimony: do not multiply entities beyond necessity. In order to show that the Buddhist can entertain the proponent's thesis and that they are, thus, entitled to reject it, they are reintroducing more entities albeit of a different kind. How did this come about? As we will see in the next section, it was Dharmakinti who planted the seeds for this development.

\section{Avoiding the Fallacy of Āśrayāsiddha Part II}

As we saw above, in the context of talking about the proponent's own subject matter (svadharmin), Dharmakīrti appeals to the method of paraphrase. ${ }^{16}$ However, he provided two strands of thought that, when they are put together, might be taken to imply the method of conceptual object as the solution to the fallacy of āśrayāsiddha. This seems to be what some Buddhist philosophers who came after Dharmakīrti did. In this section, I will present how the method of conceptual object became the main solution to āśrayāsiddha after Dharmakīti. I will then present the problems with the method as identified in the tradition.

(1) In commenting on Dignāga's discussion of svadharmin (the proponent's intended subject), Dharmakîrti distinguishes two kinds of a thesis' subject: the

\footnotetext{
${ }^{15}$ Dignāga and Dharmakīrti seem to assume that they can always paraphrase their opponents' theses. To be fair, they and other Buddhist philosophers have developed enough conventional resources to paraphrase all kinds of theses about the things that are crucial to Buddhist philosophers and non-Buddhist philosophers. I do not see, however, that there is a way of showing that paraphrasing as a general method is always available.

${ }^{16}$ See also Prajñākaragupta's (750-810 CE) commentary on Dharmakīrti's Pramāṇavārttika IV k. 141-42 in his Pramānavārttikabhāsya. A translation of the relevant passage can be found in Tillemans (1999): 177-78.
} 
subject actually intended by the proponent (svadharmin) and the subject which is 'unrelated, isolated' (kevala) (Pramānavārttika IV k. 136-48). The subject which is 'unrelated, isolated' is a 'nominal' subject (using the gloss Tibetans often give to kevala) in the sense that it is a subject that can be talked about even though it is not the actual subject (Tillemans (1999): 172-173).

(2) Dharmakīti came up with the principle that a word in the subject place of a sentence always signifies a conceptual representation (kalpanā) (e.g., PV I k. 205-212). He then applied this principle to the case of Primordial Matter and claimed that while Primordial Matter did not exist, the object of the word did exist as a conceptual object (Tillemans (1999): 175-176).

Buddhist philosophers who came after Dharmakirti combined these two strands of thought in the following way. First, in the context of (1), two of the prominent commentators of Dharmakīrti's Pramānavārttika, Devendrabuddhi (630-690 CE) and Śākyabuddhi (660-720), explain that the subject of a thesis which the proponent takes as existent but the Buddhist takes as non-existent is a nominal subject (or kevala (unrelated or isolated)). In this way, they help themselves to talk about the subject even though it is non-existent.

Śăkyabuddhi and Devendrabuddhi recognise that they cannot simply stipulate such a subject to be nominal. The problem for them (and for most Buddhist philosophers) is that they are global error theorists. Being global error theorists means that they do not think that properties can be attributed to anything, whether existent or non-existent, as they are not factual matters as discussed before. How can they show that it is false that Primordial Matter exists, for instance?

They do this by characterising properties (and reasons given for a thesis) to be mere exclusions (vyavacchedamātra). Śākyabuddhi (though not Devendrabuddhi) explains mere exclusions to be non-implicative negations (prasajyapratisedha). A negation is non-implicative if it does not entail anything positive. For instance, the negation involved in the statement 'There are not any flowers that grow in the sky' is non-implicative as it does not imply anything that grows in the sky. These negations are invoked commonly in Buddhist philosophy as a way of legitimising the lack of any positive commitment. In contrast, a negation is implicative if it does entail something positive. For instance, the negation involved in 'The rose is not red' is implicative as it implies that the rose has some other colour. ${ }^{17}$ So mere exclusions mean that there is nothing that is implied, stated or presupposed (Śākyabuddhi's Pramānavārttikațīkā D.269a4-5.) Dharmakīrti's commentators, in particular Śākyabuddhi, can then claim that the proponent's thesis can be denied without implying anything positive. And, because nothing positive is asserted by denying or negating the opponent's thesis, they do not face the fallacy

\footnotetext{
${ }^{17}$ For the contrast between non-implicative negations (prasajyapratisedha) and implicative negations (paryudāsapratisedha), see Kajiyama (1973).
} 
of āśrayāsiddha (Tillemans (1999): 173).

Second, the later Buddhist philosophers have often wheeled in Dharmakirti's principle (2) about conceptual objects as the signifiers of words generously and applied it to an understanding of the proponent's own intended subject matter (svadharmin). In particular, they took the introduction of conceptual objects as the main route to avoid āśrayāsiddha. Prajñākaragupta (750-810 CE) and Kamalaśîla (740-795 CE) as well as Tsong kha pa (1357-1419 CE), Śākya mchog ldan (1428-1507 CE)) and other Tibetans further developed on the invocation of non-implicative negations (prasajyapratisedha) and claimed that the proponent's intended subject (identified as kevaladharmin) is what the proponent takes to be real and Buddhist's intended subject (svadharmin) is not just a nominal subject but the conceptual object representing that non-existent entity. Since the subject is a conceptual object which may not have any corresponding existent entity, the Buddhist can then say that the proponent's intended subject is non-existent. And because the negation involved in the rejection of the proponent's thesis is nonimplicative, no existence of any entity or property is committed. By identifying the subject matter as conceptual object, the danger of the fallacy of ásrayāsiddha can be avoided (Tillemans (1999): 173-174). This is how the method of conceptual object became the main solution to âśrayāsiddha after Dharmakīti.

\section{Difficulties of Positing Conceptual Objects}

Is the method of conceptual objects a better solution than the method of paraphrase? By positing conceptual objects in place of the proponent's subject, the Buddhist can 'guarantee' (though it is basically a guarantee by stipulation) that the fallacy of āsrayāsiddha can always be avoided. The method of paraphrase favoured by Dignāga and Dharmakīrti lacks such guarantee as there is no guarantee that paraphrase is always available. However, introducing conceptual entities and inflating one's ontology straight after deflating it cannot be free of any difficulties. We can see some of the difficulties and complicated attempted solutions in the writing of the Mongolian scholar writing in Tibetan, A lag sha ngag dbang bstan dar (or Ngag dbang bstan dar) (1759-1840 CE), in particular in his $b$ Cig $d u$ bral gyi rnam bzhag. ${ }^{18}$

Ngag dbang bstan dar shows that the use of two types of negations, implicative and non-implicative negations, does not clearly distinguish between the cases of subject failure which are harmless because they are in the context of the nonimplicative negations and genuinely fallacious $\bar{a} s$ rayāsiddha which is problem-

\footnotetext{
${ }^{18}$ The section on āśrayāsiddha of this text has been translated in Tillemans and Lopez (1998). The discussion below will follow their translation and their extensive explanatory notes.
} 
atic. ${ }^{19}$ First, he shows that the negation involved in a thesis does not have to be non-implicative in order to avoid âsrayāsiddha. He uses the following example to show this: 'Take as the subject, a rabbit's horn; it is fitting to be designated by the word 'moon,' because it exists as an object of conceptual thought' (Tillemans \& Lopez (1998): 102). ${ }^{20}$ The property of being fit to be designated by the word 'moon' is a positive 'entity'. So, the property attributed to the subject, a rabbit's horn, is a positive 'entity' even though the subject is non-existent. Thus, the property that predicates a non-existent subject does not have to be a mere exclusion (vyavacchedamātra); it can be a positive 'entity' or an implicative negation. Second, he shows that the property attributed to the subject and the reason given for the attribution being non-implicative negations does not show that the fallacy of $\bar{a}$ śrayāsiddha is avoided. For instance, consider proving 'that [something nonexistent like a rabbit's horn] is the subtle selflessness of the elements by means of the reason, 'being the consummate [nature]'. The subject, a rabbit's horn, is non-existent even though the reason (i.e., being the consummate nature) and the property to be proved (i.e., being the subtle selflessness of the elements) are nonimplicative negations. Using examples like this, Ngag dbang bstan dar concludes that the fallacy of assrayāsiddha is avoided not when the reason and the property to be proved are non-implicative negations but when the reason and the property do not imply existence (Tillemans \& Lopez (1998): 102). That is, subject failure is problematic not necessarily when the subject is non-existent but when the properties attributed to the subject imply existence. When those properties do not imply existence, subject failure is not a problem (Tillemans \& Lopez (1998) footnote 11).

Finally, Ngag dbang bstan dar points out that the conceptual object approach to âśrayāsiddha is no better than the paraphrasing approach when it comes to the issue of changing the subject. As we saw before, the adversary can legitimately complain that the Buddhist is changing the subject when the Buddhist paraphrases their thesis. Ngag dbang bstan dar points out that the same problem arises with the method of introducing conceptual objects. For instance, for the non-Buddhist Vaiśesika, sound is permanent. The Buddhist rejects this and wants to argue that sound is impermanent. The thesis the Buddhist wants to assert has a subject that is non-existent. The Buddhist method of conceptual objects stipulates that sound is a conceptual object; ${ }^{21}$ it is not sound itself but 'what appears as sound to conceptual

\footnotetext{
${ }^{19}$ For the development of the Buddhist discussions about āśrayāsiddha, see also Klein (1991), Kobayashi (1989) and Lopez (1987).

${ }^{20} \mathrm{Ngag}$ dbang bstan dar attributes this example to 'Jam dbhyangs bzhad pa'i rdo rje (1648$1721 / 1722$ CE). However, the example cannot be found in the works of 'Jam dbhyangs bzhad pa'i rdo rje. See Tillemans \& Lopez (1998) footnote 9.

${ }^{21}$ There is a complicated story as to what exactly it means to say that sound is a conceptual object in terms of apoha (exclusion). Since the introduction of apoha does not add anything
} 
thought....a real entity (dngos po) that is independent (rang dbang ba) and is a positive phenomenon (sgrub pa)' (Tillemans \& Lopez (1998): 104). Ngag dbang bstan dar implies that the Buddhist and the Vaiśeșika are talking past each other. So the method of conceptual object faces the same difficulty as the method of paraphrasing.

This difficulty is something that Ngag dbang bstan dar himself responds. He claims that 'a mere object grasped by the auditive consciousness' concordantly appears to both parties upon hearing the word 'sound' (Tillemans \& Lopez (1998): 105). When the Buddhist and the Vaiśeșika argue about sound (or space which attracts a parallel argumentation) or when the Buddhist and the Sāmkhya argue about Primordial Matter, they are arguing about a mere verbal designation or a verbal object (sgra don). The Vaiśeșika takes sound as more than just a verbal object: it is permanent and fully real and the Sāmkhya takes Primordial Matter as more than just a verbal object, i.e., fully real. Nevertheless, there are 'concordantly appearing subjects' (chos can mthun snang $b a$ ) for both parties. ${ }^{22}$

What is crucial here is the distinction between 'the exclusion qua thing itself (rang ldog) and the exclusion qua basis [for the thing] (gzhi ldog)' (Tillemans \& Lopez (1998): 106). The distinction is between the thing itself and an instance of it under a description. Ngag dbang bstan dar uses this distinction to argue that the Buddhist and their opponent are both arguing about a verbal object, an object under some description, even though neither party recognises it as such (Tillemans \& Lopez (1998) footnote 30). He then concludes that there is no problem in changing the subject. Both parties are talking about the same thing. It is just that the opponent wrongly thinks that the object in question is something more than this and thinks that it is fully real.

Is this a plausible solution? In order to deal with a problem that arose by the introduction of conceptual objects, Ngag dbang bstan dar appeals to yet another conceptual apparatus: concordantly appearing subjects. Perhaps, constantly introducing new conceptual apparatus and continuously keeping the conceptual realm fine-grained, the Buddhist can come to prove that non-existent things do not exist. But how rich our conceptual life would have to be to prove that the self, a non-existent entity, does not exist? I will leave this question unanswered.

substantive in the present context, I refrain from spelling it all out. For discussions on apoha, see Siderits, Tillemans \& Chakrabarti (2011).

${ }^{22}$ The notion of 'concordantly appearing subject' seems to be a Tibetan development, though there is an Indian precedence of problematising the lack of commonly acknowledged ( $u b$ hayaprasiddha) subjects in debates. For the development of 'concordantly appearing subject', see Lopez (1987), Hopkins (1989) and Tillemans (1990). 


\section{Conclusion}

How can Buddhists prove that non-existent things do not exist? With great difficulty. For the Buddhist, this is not a laughing matter as they are largely global error theorists and, thus, many things are non-existent. The difficulty gets compounded as the Buddhist and their opponent, the non-Buddhist of various kinds, both agree that one cannot prove a thesis whose subject is non-existent. Buddhist philosophers have developed mainly two strategies to avoid this difficulty: the method of paraphrase and the method of conceptual objects. Early Buddhist philosophers proposed the method of paraphrase as the solution to the difficulty of talking about non-existent things. This proposal, however, was not taken up by the later Buddhist philosophers. What became the main approach to argue about nonexistent things is the method of conceptual objects. But this strategy imports all of the problems associated with a separate issue into what is already a minefield. Rather than addressing the question of how to argue about non-existence, the later Buddhist philosophers have, in addition, taken themselves to be tasked with explaining why it is not puzzling to bring non-existence into existence of some sort. As we saw, that multiplied the problems requiring them to come up with ingenious attempts to solve the difficulties. What the history of Buddhist philosophy would look like if the method of paraphrase was further developed and adopted widely? We would never know. That history is non-existent and that is where we have to be silent.

\section{References}

Brock, S., 2002. 'Fictionalism about Fictional Characters', Noûs 36: 1-21.

Cowherds, The, 2011. Moonshadows: Conventional Truth in Buddhist Philosophy, Oxford: Oxford University Press.

Hopkins, J., 1989. 'A Tibetan Delineation of Different Views of Emptiness in the Indian Middle Way School', Tibet Journal 1: 10-43.

Joyce, R., 2016. 'Moral Anti-Realism', Stanford Encyclopedia of Philosophy (Winter 2016), Edward N. Zalta (ed.).

Kajiyama, Y., 1973. 'Three Kinds of Affirmation and Two Kinds of Negation in Buddhist Philosophy', Wiener Zeitschrift für die Kunde Südasiens 17: 161-175.

Katsura, S., 1992. 'Dignāga and Dharmakīrti on adarśanamātra and anupalabdhi', Asiatische Studien/Etudes Asiatiques 46: 222-231.

Keira, R., 2004. Mādhyamika and Epistemology, Wien: Arbeitskreis für tibetische und buddhistische Studien Universität Wien.

Klein, A., 1991. Knowing, Naming and Negation, Ithaca: Snow Lion Publications.

Kobayashi, M., 1989. 'The Mādhyamika Argument for nihsvabhāvatā and the Fallacy of āṣrayāsiddha: Kamalaśîla's View in the Madhyamakāloka', Bunka 50: 218-299. 
Lopez, D., 1987. A Study of Svātantrika, Ithaca: Snow Lion Publications.

Matilal, B., 1970. 'Reference and Existence in Nyāya and Buddhist Logic', Journal of Indian Philosophy 1: 83-110.

Patil, P., 2009. Against a Hindu God, New York: Columbia University Press.

Siderits, M., Tillemans, T. \& Chakrabarti, A. (eds.), 2011. Apoha, New York: Columbia University Press.

Tillemans, T., 1990. Materials for the Study of Āryadeva, Dharmapāla and Candrakīrti, Wien: Arbeitskreis für tibetische und buddhistische Studien Universität Wien. 1999. Scripture, Logic, Language, Boston: Wisdom Publications. 2016. How Do Mādhyamikas Think?, Somerville: Wisdom Publications. and Lopez, D., 1998. 'What Can One Reasonably Say About Nonexistence? A Tibetan Work on the Problem of Āsrayāsiddha', Journal of Indian Philosophy 26: 99-129.

Tanaka, K., 2013. 'Buddhist Philosophy of Logic', A Companion to Buddhist Philosophy, Steven M. Emmanuel (ed.), Chichester: Wiley-Blackwell, 320-330.

forthcoming. 'Buddhist Shipping Containers', Reasons and Empty Persons, C. Coseru (ed.), Dordrecht: Springer. 